\title{
Assessment of Heavy Metals Concentration in Mangroves Leaves of the Red Sea Coast of Yemen
}

\section{Al Hagibi HA*, Nagi HM, Al-Selwi KM and Al-Shwafi NA \\ Department of Earth and Environmental Sciences, Sana'a University, Yemen}

*Corresponding author: Hagib A Al-Hagibi, Department of Earth and Environmental Sciences, Faculty of Science, Sana'a University, Yemen, Tel: 00967777322298; Email: Hagib_2002@Hotmail.com

\section{Research Article}

Volume 2 Issue 1

Received Date: January 28, 2018

Published Date: February 20, 2018

DOI: $10.23880 /$ jenr-16000120

\section{Abstract}

The present research work focuses on the concentration of $\mathrm{Pb}, \mathrm{Cd}, \mathrm{Cr}, \mathrm{Ni}, \mathrm{Co}, \mathrm{Cu}, \mathrm{Zn}, \mathrm{Mn}, \mathrm{Mg}$ and Fe in mangrove leaves. Samples were collected seasonally at five locations on Yemeni Rea Sea coast: Al-Salif, Al-Urj, Al-Hodeidah, Yakhtol, and Ghorairah, during the months of January, April, August and October 2013, which are chosen to represent the four seasons of a full year. Atomic Absorption Spectroscopy techniques were used to determine concentration of heavy metals in the samples, which extracted using Acid digestion methods. The results showed that heavy metals concentrations ( $\mu$ g/g) in mangrove leaves were in the following order: Mg (987.5-1,743.7) > Fe (201.0-486.0) > Cu (10.2-25.6) > Zn (13.2-23.1) > Mn (8.6-19.1) > Ni (1.9-4.8) > Cr (1.2-3.9) > Co (0.4-2.6) > Pb (ND-3.5) > Cd (ND-0.5). The levels of studied metals in mangrove leaves were comparable with corresponding in other less polluted areas of the world. Concentration of these metals in mangrove leaves were lower than the permissible limits as recommended by $\mathrm{WHO}, \mathrm{except} \mathrm{Mg}, \mathrm{Cu}, \mathrm{Cr}, \mathrm{Pb}$, and $\mathrm{Cd}$. Relatively high metals concentration at Al-Hodeidah could be due to increasing anthropogenic activities in the vicinity of the site, whereas at Ghorairah may be attributed to the potential contaminants that carried by water currents coming from the Gulf of Aden, through Bab-el-Mandeb Strait. Al-Salif and Yakhtol found to be not polluted by these metals. This might be due to limited influence of anthropogenic activities at these two sites. Higher heavy metals concentration during spring and summer may be associated with increasing biological activities, land run off and rainfall during these seasons. Continuous monitoring of these metals in mangrove habitats to avoid being overcome permissible limits. These findings could be used as database toward future ecological studies, conservation and sustainable management of the Yemeni mangrove habitats located in the Red Sea Coast.

Keywords: Heavy Metals; Mangrove; Habitats; Red Sea; Yemen 


\section{Journal of Ecology \& Natural Resources}

\section{Introduction}

Mangrove forests are among of the most productive and biologically important ecosystems of the world because they provide important and unique ecosystem goods and services to human society and coastal and marine ecosystems $[1,2]$. They serve as nursery and breeding grounds for several commercially important species of marine fauna, as well as protecting coastlines from the devastating effects of erosion [3]. Mangrove ecosystems play an important role in the biogeochemistry of heavy metal contaminants in tropical coastal areas [4]. Heavy metals are one of the most serious pollutants in natural environment due to their toxicity, persistence and bioaccumulation problems with the long residence time within the food chains [5]. Numerous studies have utilized mangrove species as reliable bio-indicators for heavy metal pollution and contamination [6-9]. Due to the bioaccumulation potential and metal toxicity the persistence and cycling of heavy metals is of a serious concern in mangrove environment [10-13]. The heavy metals being biologically non degradable would be transferred and concentrated into plant tissues from soils and pose long term damaging effects on plants [14-16]. However, a number of researchers have found elevated levels of heavy metals in leaf tissue for many mangrove species such as: Rhizophora spp. and Avicennia spp. $[17,18]$. This quality qualifies Avicennia marina to be a good bioindicator and enables researchers to obtain quantitative information about the environmental quality of its habitat through monitoring and experimental testing [19]. Mangrove forests are one of the important vegetations on the Red Sea coast of Yemen and are dominated by Avicennia marina. However, the mangrove ecosystems have remained neglected specifically with reference to such studies. Very poor information is available regarding heavy metals pollution in the mangrove ecosystems of Yemen. Therefore an attempt was made through this study to find out the status of ten heavy metals ( $\mathrm{Pb}, \mathrm{Cd}, \mathrm{Cr}, \mathrm{Ni}, \mathrm{Co}, \mathrm{Cu}, \mathrm{Zn}, \mathrm{Mn}, \mathrm{Mg}$ and $\mathrm{Fe}$ ) in mangrove leaves of Yemen particularly those in the Red Sea coast. Distribution pattern of some selected heavy metals in mangrove leaves are determined to understand the roles of mangrove plants in their cycling.

\section{Materials and Methods}

\section{Study Area}

The area under investigation is laying from the south eastern part of the Red Sea in the coast of Yemen. It extends from Al-Salif which is located at latitude $15^{\circ} 12^{\prime}$ $35^{\prime \prime} \mathrm{N}$ and longitude $42^{\circ} 46^{\prime} 16^{\prime \prime} \mathrm{E}$ to Bab-el-Mandeb Strait in the south at $12^{\circ} 44^{\prime} 33^{\prime \prime} \mathrm{N}$ latitude and $43^{\circ} 28^{\prime}$ $22 " \mathrm{E}$ longitude. The distinctive areas are namely Al-Salif, Al-Urj, Al-Hodeidah, Yakhtol and Ghorairah (Figure 1). Sampling was carried out on seasonally basis during the year 2013. Samples were collected during the months of January, April, August and October 2013, which are chosen to represent the four seasons of a full year. Location of selected stations were determined by geographical position system GPS (Digital Garmin eTrex Vista C) (Table 1).

\begin{tabular}{|c|c|c|c|}
\hline \multirow{2}{*}{ Station No. } & \multirow{2}{*}{ Nearest City } & \multicolumn{2}{|c|}{ Location of Station } \\
\cline { 3 - 4 } & Al-Salif & $15^{\circ} 12^{\prime} 35^{\prime \prime} \mathrm{N}$ & Longitudes (East) \\
\hline St-1 & Al-Urj & $15^{\circ} 05^{\prime} 51^{\prime \prime} \mathrm{N}$ & $42^{\circ} 46^{\prime} 16^{\prime \prime} \mathrm{E}$ \\
\hline St-2 & Al-Hodeidah & $14^{\circ} 52^{\prime} 02^{\prime \prime} \mathrm{N}$ & $42^{\circ} 52^{\prime} 16^{\prime \prime} \mathrm{E}$ \\
\hline St-3 & Yakhtol & $13^{\circ} 31^{\prime} 03^{\prime \prime} \mathrm{N}$ & $42^{\prime} 10^{\prime \prime} \mathrm{E}$ \\
\hline St-4 & Ghorairah & $12^{\circ} 44^{\prime} 33^{\prime \prime} \mathrm{N}$ & $43^{\circ} 15^{\prime} 55^{\prime \prime} \mathrm{E}$ \\
\hline St-5 & & $43^{\circ} 28^{\prime} 22^{\prime \prime} \mathrm{E}$ \\
\hline
\end{tabular}

Table 1: Geographical locations of the sampling stations

\section{Samples Collection and Analysis}

A rapid survey of mangrove environment at selected sites was conducted for selection of six sub-stations, which represent the site entirely; these sub-stations were used to sampling during the four seasons.

Mangrove leaves samples of Avicennia marina were handpicked from different parts of the trees in the same six sub-stations, then mixed up to obtain a sample of leaves representing all mangroves trees in site during the four seasons. Mangrove leaves samples were split and washed to the sand using the deionized water, to ensure the complete removal of sand on mangrove leaves, then dried in the oven at $50^{\circ} \mathrm{C}$ for 24 hours. Thereafter, the leaves were grind using a mortar and pestle to a homogenous and sieved through a $1 \mathrm{mms}$ mesh sieve. Sieved samples stored in polyethylene containers at a room temperature until digested. Gloves were used in all handling stages to avoid contamination. Digestions were performed following the procedure as described by APHA (2005) [20]. 


\section{Journal of Ecology \& Natural Resources}

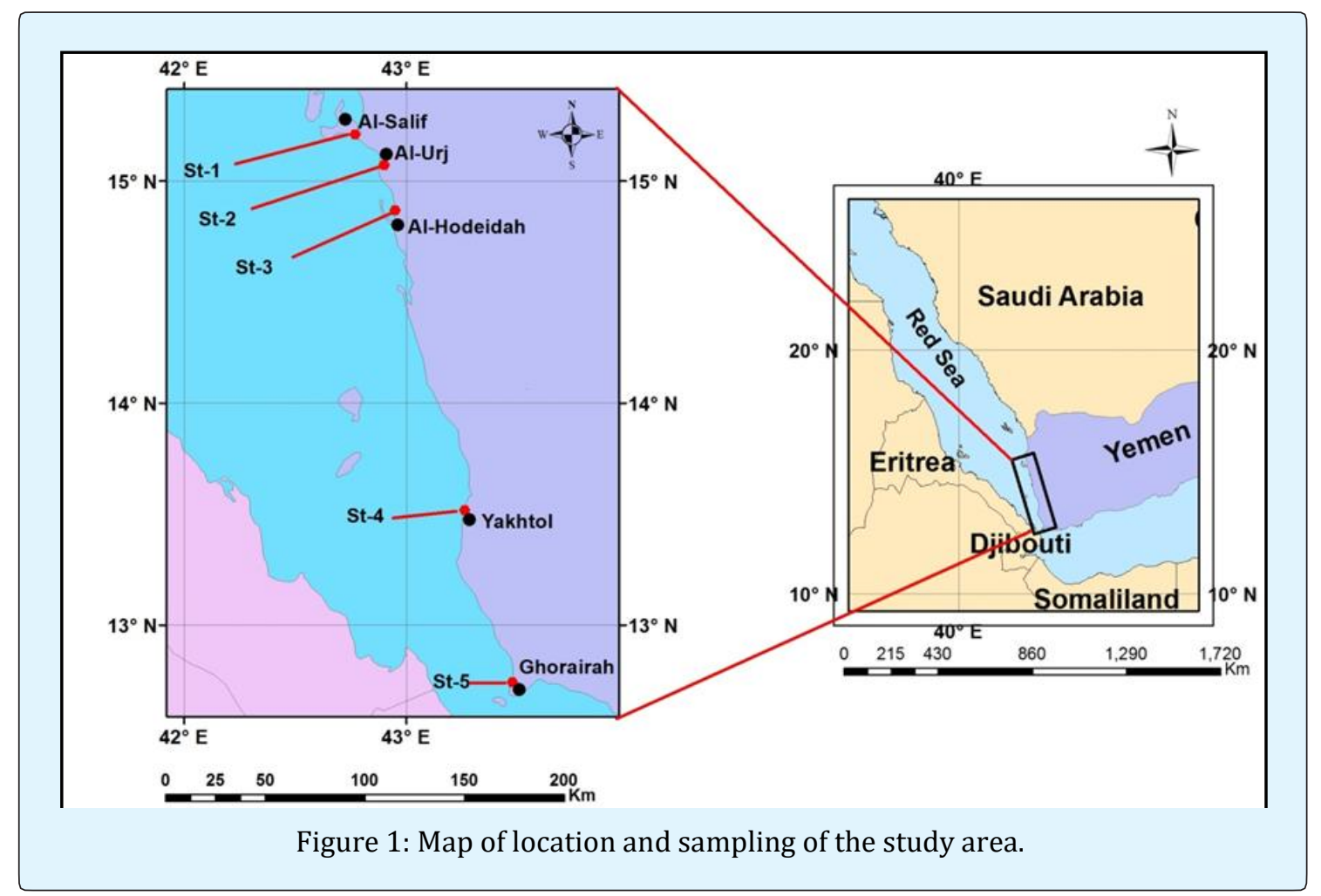

For each sieved powdered samples were homogenized in its container, exactly $3 \mathrm{~g}$ of leaves was used in the digestion process, and the same procedures were used for each sample. The weighted samples were wet digested where put into $250 \mathrm{ml}$ Teflon beaker with $2.5 \mathrm{ml}$ of concentrated perchloric acid $\left(\mathrm{HClO}_{4}\right)$ and $7.5 \mathrm{ml}$ of concentrated nitric acid $\left(\mathrm{HNO}_{3}\right)$. The beaker were covered with glass plates in the fume hood and allowed to predigest overnight at room temperature. The beaker placed on a hot plate at $70^{\circ} \mathrm{C}$ for two hours. The solution filtered into $250 \mathrm{ml}$ Teflon beaker using Whatman $0.45 \mu \mathrm{m}$. After cooling at room temperature, $2-3 \mathrm{ml}$ deionized water was added to dilute each sample. Beaker reheated on a hot plate at $70^{\circ} \mathrm{C}$, and solution reduced $1-2$ $\mathrm{ml}$. The solution filtered into a $50 \mathrm{ml}$ volumetric flask, using Whatman $0.45 \mu \mathrm{m}$ filter paper which allows only dissolved constituents to pass though and made the final volume to a $50 \mathrm{ml}$ by deionized water. For background correction, Blank solution was prepared for each type of samples sediment and leaves by treated in the same way of those digested of samples without samples. The digested samples and blank solution samples were transferred into separate plastic bottles, labeled and stored waiting for analysis in line with the method described by Perkin-Elmer Corporation (1996) [21].

Many analytical methods including Atomic Absorption Spectrometry (AAS) for heavy metal determination in plant material require the digestion of the samples [22]. Because of its sensitivity, specificity, simplicity and precision, AAS is the most widely recommended instrument utilized in analytical procedures for metal analysis $[23,24]$. The filtered samples were analyzed using Perkin Elmer AAS Model 2380, according to the manufacture's instruction. The total metals concentration in each sample was calculated using Eq.1 [25]:

$$
E=(A \times B) / D(\text { Eq.1) }
$$

Where; $E$ is concentration of metal in sample $(\mu \mathrm{g} / \mathrm{g}), A$ is metal concentration in calibration curve $(\mu \mathrm{g} / \mathrm{l}), B$ is final volume of sample ( $\mathrm{ml}$ ) and $D$ is dry weight of sample (g).

\section{Results and Discussion}

The seasonal results of concentrations of $\mathrm{Pb}, \mathrm{Cd}, \mathrm{Cr}, \mathrm{Ni}$, $\mathrm{Co}, \mathrm{Cu}, \mathrm{Zn}, \mathrm{Mn}, \mathrm{Mg}$ and $\mathrm{Fe}$ in mangrove leaves collected from the study area have been represented in Figure 2.

\section{Lead (Pb)}

Lead occurs as metallic lead and inorganic and organometallic compounds [26,27]. It is nonessential element as it is toxic even in trace amount. $\mathrm{Pb}$ has no known biological role in plants and is highly toxic to aquatic life; it exerts adverse effect on morphology, growth and photosynthetic processes of plants [28]. 


\section{Journal of Ecology \& Natural Resources}

Elevated levels of $\mathrm{Pb}$ could be directly detrimental to the health of the aquatic ecosystem and indirectly to man [27]. It is considered to be potentially hazardous and toxic to most forms of life, and relatively accessible to aquatic organisms. It poses a threat even at extremely low concentrations [29]. Plants normally absorb only a little amount of lead [30].

The value of $\mathrm{Pb}$ in mangrove leaves ranged from undetectable levels at Al-Salif in October and Yakhtol in January, August and October to $3.5 \mu \mathrm{g} / \mathrm{g}$ at Al-Hodeidah in August. The values of $\mathrm{Pb}$ in mangrove leaves at $\mathrm{Al}$ Hodeidah and Ghorairah were slightly higher than the permissible limit of lead in plants, which is reported to be $2.0 \mu \mathrm{g} / \mathrm{g}$ by WHO (1996) [31]. This study suggests that mangrove in the investigated sites not polluted by $\mathrm{Pb}$ at Al-Salif and Yakhtol. This might be due to limited influence of anthropogenic activities at these two sites. On the other hand, Al-Hodeidah and Ghorairah exhibited low to moderate contamination, which might be attributed to the increased anthropogenic activities in the vicinity of these two sites Zheng WJ (1997) and Machado W (2002) $[32,33]$ suggested that non-essential metals could be accumulated in leaf and then removed from the tree with falling leaves. The present results also indicate that nonessential metals such as $\mathrm{Pb}$ and $\mathrm{Cd}$ could be accumulated in mangrove leaves. The sources of $\mathrm{Pb}$ in mangrove ecosystems include industrial wastes and from water pipes [34]. Other sources of $\mathrm{Pb}$ are lead acid batteries, solder, alloys, cable sheathing, pigments, rust inhibitors, ammunition, glazes and plastic stabilizers [35].

\section{Cadmium (Cd)}

Cadmium in plants has no essential biological function, whereas it tends to accumulate in plants and aquatic biota, with consequent problems of toxicity [36]. It may cause several physiological, biochemical and structural changes [5,37]. Cd has been shown to be one of the most effective inhibitors of photosynthetic and enzymatic activities [38]. It could produce disturbances in plant antioxidant defenses giving rise to oxidative stress [39].

The present investigation also showed a very narrow range in values of $\mathrm{Cd}$ in mangrove leaves. It varied from undetectable levels at Al-Salif in January and Yakhtol in October to $0.5 \mu \mathrm{g} / \mathrm{g}$ at Al-Urj. The results of present study exhibited a relatively slight increase in the concentrations of $\mathrm{Cd}$ at $\mathrm{Al}$-Urj compared with other sites might be due to the increasing in size and age of mangrove trees in this site. [40] Reported that Cd increases in concentration with plant growth. The values of $\mathrm{Cd}$ in mangrove leaves were higher than the permissible limit of $\mathrm{Cd}$ in plants, which is reported to be $0.02 \mu \mathrm{g} / \mathrm{g}$ by WHO (1996) [31].
Normally, plants in unpolluted environment contain 0.01 $0.3 \mu \mathrm{g} / \mathrm{g}$ of Cd [41]. Based on background Cd levels in plants, mangrove trees might be classified as no unpolluted at Yakhtol and Al-Salif, whereas at Al-Urj, AlHodeidah and Ghorairah, mangrove trees classified as low polluted. Cd in mangrove ecosystems could be derived from both natural and anthropogenic sources. Natural sources include underlying bedrock or transported parent material such as alluvium. Anthropogenic sources include industrial effluents, wastes, urban runoff, burning of fossil fuels, sewage treatment plants, boating activities, aerial deposition, sewage, domestic garbage dumps, manure, and phosphate and fertilizers application $[42,43]$.

\section{Chromium (Cr)}

Chromium is an essential micronutrient for plants [44]. Although this metal is essential for plants development, but easily absorbed by epidermis and root of plants and then enter to wood tissue from internal or external membrane [45]. The effects of toxicity of $\mathrm{Cr}$ are include of reducing in productivity and growth of root and aerial parts of plants which is caused by reducing in photosynthesis, limiting of enzyme activities and inducing action of mutants [46].

The level of $\mathrm{Cr}$ in mangrove leaves ranged from $1.2 \mu \mathrm{g} / \mathrm{g}$ in October at Yakhtol to $3.9 \mu \mathrm{g} / \mathrm{g}$ in April at Al-Salif. The recorded values of $\mathrm{Cr}$ in mangrove leaves of the present study (especially at Al-Hodeidah and Ghorairah) were higher than the permissible limit of this metal in plants, which is reported to be $1.30 \mu \mathrm{g} / \mathrm{g}$ by WHO (1996) [31]. At Al-Hodeidah and Ghorairah, the mangrove trees showed low to moderate contaminated. These findings suggest that mangrove leaves have ability to tolerate and accumulate of $\mathrm{Cr}$. These results agreed with many authors $[47,48]$. The main natural source of $\mathrm{Cr}$ in mangrove environments could be derived from the weathering of rocks and soil, whereas major anthropogenic sources includes metal alloy production, metal plating for prevention of corrosion, tannery wastes, cement manufacturing, leather manufacturing wastes, paint pigments, incineration of municipal refuse and sewage sludge $[34,49]$.

\section{Nickel (Ni)}

Nickel is essential heavy metals for plants, whereas excessive nickel levels in the soil could be result in toxicity to plants [50]. The common indicators of nickel phytotoxicity to plants include inhibition of germination, leaf spotting, chlorosis, abnormal flower shape, reduced growth of roots and shoots, deformation of plant parts, poor branching and decreased yield [51]. Ni also affects 


\section{Journal of Ecology \& Natural Resources}

various physiological and biochemical processes in higher plants [52]. Plants could take up nickel through the roots by both passive diffusion and active transport mechanisms [53].

The concentrations of $\mathrm{Ni}$ in mangrove leaves during the present study ranged from $1.9 \mu \mathrm{g} / \mathrm{g}$ in April at Yakhtol to $4.8 \mu \mathrm{g} / \mathrm{g}$ in August at Al-Hodeidah. Normal Ni concentration in plants ranges from $0.5-5 \mu \mathrm{g} / \mathrm{g}$ and values above these values are poisonous [41]. The concentrations of $\mathrm{Ni}$ in mangrove leaves were within the range of the permissible limit of nickel in plants, which is reported to be $10.0 \mu \mathrm{g} / \mathrm{g}$ by WHO (1996) [31]. Relatively high concentration of $\mathrm{Ni}$ is found in mangrove leaves at Al-Hodeidah, this might be due to influence of anthropogenic activities at this site. The present study shows that mangrove leaves are capable of accumulating nickel as reported by Kaewtubtim P, et al. (2016) [19]. Ni contaminations in mangrove ecosystems of the study area are metal plating industries, combustion of fossil fuels and electroplating [54]. Other sources of $\mathrm{Ni}$ include weathering process of exposed soil, decaying vegetation and the $\mathrm{Ni} / \mathrm{Cd}$ batteries dumped in these sites [55].

\section{Cobalt (Co)}

Cobalt has been shown to affect the growth and metabolism of plants [56]. Toxic effects of Co on plants include inhibited active transport of ions, photosynthetic inefficiency, and change in morphology, impaired DNA replication, RNA synthesis and alteration of the sex of plants [57]. The present study showed a narrow range in Co levels in mangrove leaves. It ranged from $0.45 \mu \mathrm{g} / \mathrm{g}$ at Yakhtol to $2.93 \mu \mathrm{g} / \mathrm{g}$ at Ghorairah. As a result of the presence of cobalt in the soil and sediments, it has been detected in living plants, as well at a mean level of $0.48 \mu \mathrm{g} / \mathrm{g}$ [58]. The cobalt flower plant could actually hyperaccumulate cobalt at a mean level of $4.3 \mu \mathrm{g} / \mathrm{g}$ dry weight [59]. Slightly high values of Coin mangrove leaves at Al-Hodeidah may be related to effects of the anthropogenic activities on the mangrove habitat. Naturally, Co could be discharged into the environment from wind-blown dust, seawater spray, volcanoes and continental and marine biogenic emissions [60]. Anthropogenic sources of Co could be from burning of fossil fuels, sewage sludge, and phosphate fertilizers, processing of cobalt alloys and industries that use or process cobalt compounds $[61,62]$.

\section{Copper (Cu)}

Copper is an essential micronutrient necessary for enzyme function, metabolism, protein synthesis and detoxification but an excess could cause toxicity [63]. $\mathrm{Cu}$ is also an essential micronutrient required in the growth of plants, it is bound to amino acids and transported through the xylem [64]. The levels of $\mathrm{Cu}$ in mangrove leaves ranged from $10.2 \mu \mathrm{g} / \mathrm{g}$ in January at Al-Salif to $25.6 \mu \mathrm{g} / \mathrm{g}$ in August at Al-Hodeidah. The levels of $\mathrm{Cu}$ in mangrove leaves in the present study were higher than the permissible limit of copper in plants, which is reported to be $10.0 \mu \mathrm{g} / \mathrm{g}$ by WHO (1996) [31]. Generally, $\mathrm{Cu}$ showed the highest concentrations in mangrove leaves in all sites (especially at Al-Hodeidah). These results suggest that the mangroves have shown high capacity to accumulate of $\mathrm{Cu}$. Same finding are reported by Badarudeen A, et al. (2014) [18]. Accumulation of $\mathrm{Cu}$ in leaves at levels between 15 and $25 \mu \mathrm{g} / \mathrm{g}$ could because toxic effects, including photosynthesis inhibition, reduction in carbohydrate and nitrogen metabolism and chromosome damage [65]. The average content of $\mathrm{Cu}$ in plant is $10.0 \mu \mathrm{g} / \mathrm{g}$ [66]. This study suggests that mangrove trees in all investigated sites polluted by copper especially at Al-Hodeidah. Naturally, $\mathrm{Cu}$ could be discharged into mangrove environment from forest fires, weathering process of exposed soil and decaying vegetation. Anthropogenic source of copper may originate from domestic use of copper-based chemicals, municipal untreated sewage sludge and corrosion of copper materials [67]. In addition to domestic and industrial wastewaters, steam electrical production, incinerator emissions and the dumping of sewage sludge [68].

\section{Zinc (Zn)}

Zinc is an essential and beneficial element for plants [69]. It acts as a catalytic or structural component in many enzymes that are involved in energy metabolism and in transcription and translation of RNA [70]. Zn plays a vital role in the physiological and metabolic process of many organisms it is important for immune function and is needed for DNA synthesis [44].

The levels of $\mathrm{Zn}$ of the present study showed the highest levels in mangrove leaves in all sites. It ranged between $13.2 \mu \mathrm{g} / \mathrm{g}$ at Yakhtol in October and $23.1 \mu \mathrm{g} / \mathrm{g}$ at $\mathrm{Al}$-Hodeidah in April. The recorded values of $\mathrm{Zn}$ in mangrove leaves of the present study were lower than the permissible limit of $\mathrm{Zn}$ in plants, which is reported to be $50.0 \mu \mathrm{g} / \mathrm{g}$ by WHO (1996) [31]. Mangrove plant at all sites showed unpolluted by zinc. This study suggests that mangrove leaves had ability to accumulate of zinc. Some findings reported by Badarudeen A, et al. (2014) [18] and MacFarlane GR (2002) [71]. Main sources of Zn discharge into mangrove ecosystems include automobiles, petroleum refining, pulp and paper industry, steel industry, organic chemicals, inorganic chemicals, fertilizers and metal plating $[72,73]$. The other possible 
sources of $\mathrm{Zn}$ are from motor oil, grease, phosphate fertilizers, sewage sludge, transmission fluid and concrete [74].

\section{Manganese (Mn)}

Manganese is an essential plant mineral nutrient, playing a key role in several physiological processes, particularly photosynthesis [75]. In plants, Mn ions are transported to the leaves after uptake from soils [76]. Mn toxicity is a relatively common problem compared to other micronutrient toxicity [77]. It has two roles in the plant metabolic processes: as an essential micronutrient and as a toxic element when it is in excess [78].

The concentrations of $\mathrm{Mn}$ in mangrove leaves of the study area varied from $8.6 \mu \mathrm{g} / \mathrm{g}$ in January at Yakhtol to $19.1 \mu \mathrm{g} / \mathrm{g}$ in August at Al-Hodeidah. Normal manganese contents of leaves differ greatly between species 20 $50 \mu \mathrm{g} / \mathrm{g}$ [79]. The levels of $\mathrm{Mn}$ in mangrove leaves at all sites were within this range. The present study suggests that the mangrove ecosystems unpolluted by Mn. The natural sources of $\mathrm{Mn}$ in mangrove environments could be from weathering of rocks and soils, decaying vegetation [80]. Anthropogenic source could be from municipal wastewater discharges, sewage, and sludge, emissions from ferroalloy and iron production, as well as combustion of fossil fuels [81].

\section{Magnesium (Mg)}

Magnesium is an essential element for plant growth and development. It is necessary for chlorophyll pigment in green plants [82]. It has a wide range of key roles in many plant functions, one of the magnesium's well-known roles is in the photosynthesis process, as it is a building block of the Chlorophyll, which makes leaves appear green [83]. Deficiencies of $\mathrm{Mg}$ are much more common than problems concerned with toxicity [82].
The present study showed the highest concentrations of $\mathrm{Mg}$ in mangrove leaves at all sites it compared with concentrations of other investigated metals. It ranged


at Al-Hodeidah in August. The values of $\mathrm{Mg}$ in mangrove leaves were higher than the permissible limit of magnesium in plants, which is reported to be $200 \mu \mathrm{g} / \mathrm{g}$ by WHO (1996) [31]. These results indicate that mangroves have high tolerance to accumulate of magnesium. Same finding are reported by Kathiresan K, et al. (2014) [84]. Naturally, Mg could be discharged into the mangrove ecosystem from weathering process of exposed soil and decaying vegetation, while anthropogenic sources include discharges, fertilizers, spills from industrial and municipal waste treatment plants $[85,86]$.

\section{Iron (Fe)}

$\mathrm{Fe}$ as an essential element for all plants has many important biological roles in the processes as diverse as photosynthesis, chloroplast development and chlorophyll biosynthesis [87]. It plays important roles in the electron transport chains associated with photosynthesis and respiration [22]. Iron is toxic when high levels accumulate, it could act catalytically via the Fenton reaction to generate hydroxyl radicals, which could damage lipids, proteins and DNA [88,89]. Therefore, plants must respond to iron stress in terms of both iron deficiency and iron overload [2]. Fe is the third most limiting nutrient for plant growth and metabolism, primarily due to the low solubility of the oxidized ferric form in aerobic environments [90]. Iron deficiency is a common nutritional disorder in many crop plants, resulting in poor yields and reduced nutritional quality [91]. Iron sulphate is also used as a fertiliser and herbicide [92].

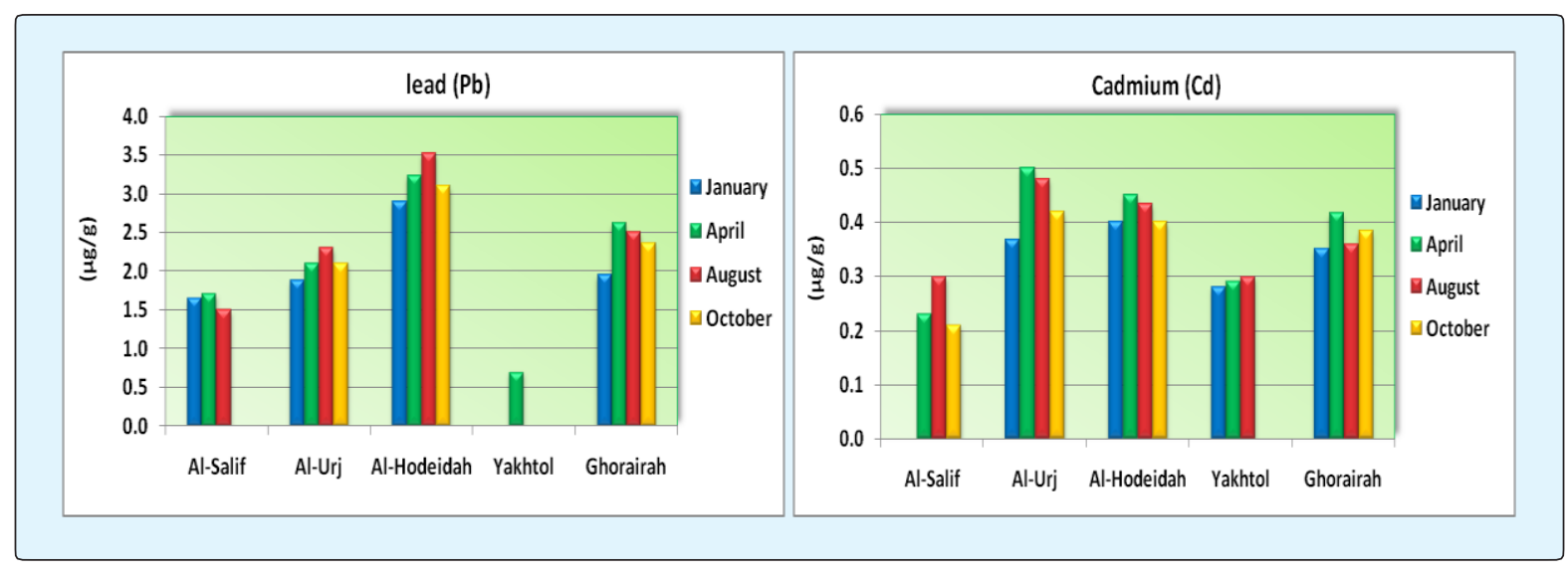

Al Hagibi HA, et al. Assessment of Heavy Metals Concentration in Mangroves Leaves of the Red Sea Coast of Yemen. J Ecol \& Nat Resour 2018, 2(1): 120. 


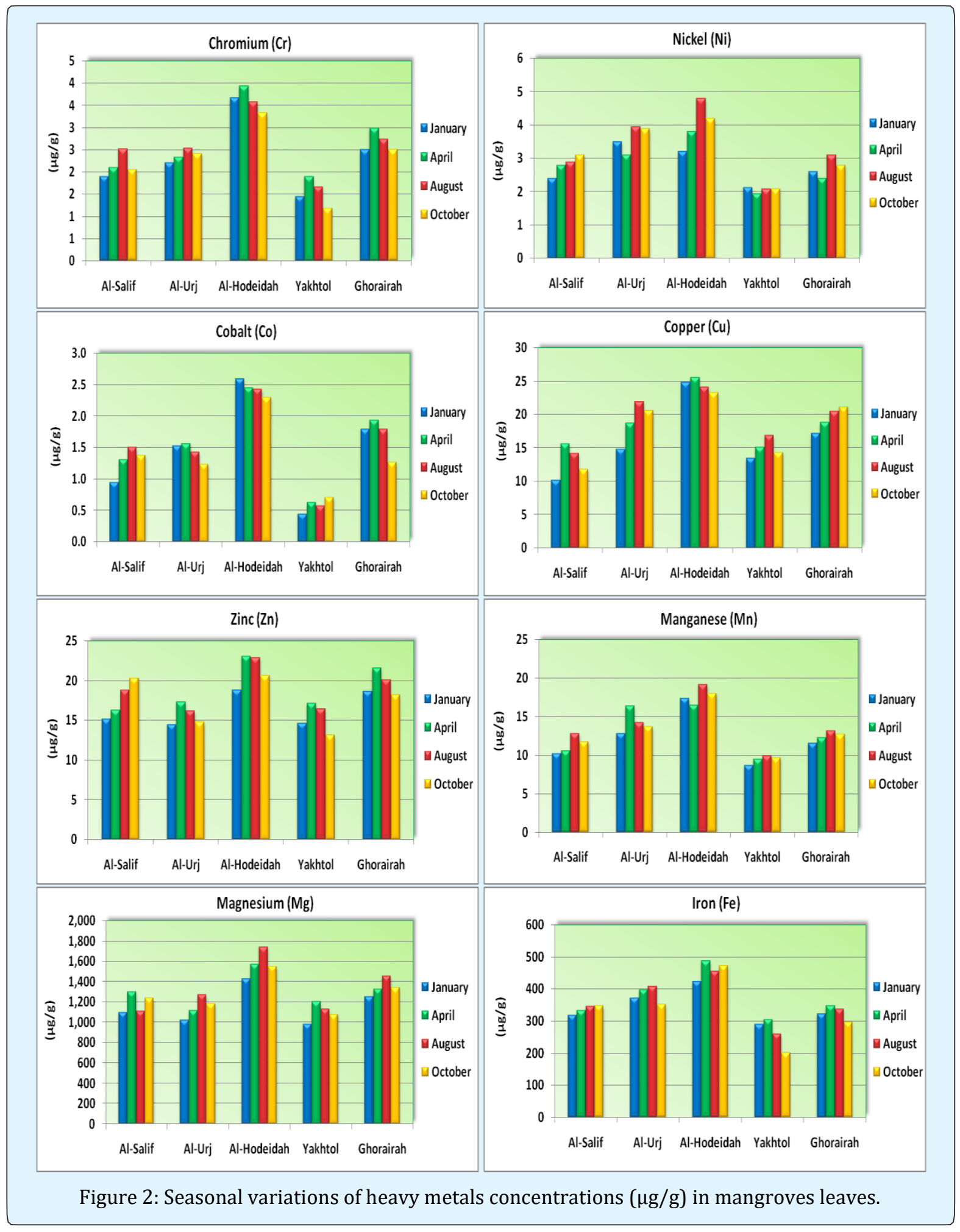

The levels of $\mathrm{Fe}$ in mangrove leaves ranged from $201.0 \mu \mathrm{g} / \mathrm{g}$ at Yakhtol in October to $486.0 \mu \mathrm{g} / \mathrm{g}$ at $\mathrm{Al}-$
Hodeidah in April. High values at Al-Hodeidah may be related to effects of the sewage treatment plant output 
into the mangrove habitat. Fe values in mangrove leaves were lower than the permissible limit of iron in plants, which is reported to be $450.0 \mu \mathrm{g} / \mathrm{g}$ by FAO/WHO (1984) [93]. This study suggests that the mangrove trees in all sites not polluted by $\mathrm{Fe}$ except at Al-Hodeidah. These findings also suggest that mangrove leaves have ability to tolerate and accumulate of iron. These results agreed with many authors [18,84]. Fe is released into mangrove ecosystems by natural process, such as weathering of sulphide ores and rocks [94]. Anthropogenic sources of Fe include the iron and steel industry, burning of coke and coal, sewage, landfill leachates and the corrosion of iron and steel [95].

The essential metals ( $\mathrm{Mg}, \mathrm{Fe}, \mathrm{Mn}, \mathrm{Zn}$ and $\mathrm{Cu}$ ) have a part to play in chloroplast processes, protein synthesis, enzyme activities, growth hormones and carbohydrate metabolisms $[18,96]$. High levels of these metals in mangrove leaves may be that these metals are micronutrients essential metals for mangrove growth and metabolism and thus absorbed and used by mangrove plants. Comparing the concentration of studied metals in mangrove leaves of the study area with those from other studies conducted within the same geographical region and other countries shown in Table 2.

The present investigation showed that the heavy metals concentrations in mangrove leaves varied from not polluted to slightly higher the permissible limits which are reported by WHO. Magnesium, Copper, Chromium, Lead, and Cadmium were slightly exceeded the permissible limits, whereas Cobalt, Nickel, Zinc, Manganese, and Iron were within the permissible limits of WHO. It is clear from the present results that the samples collected from Al- Hodeidah and Ghorairah stations were relatively higher in heavy metals concentration than the other locations which indicate more anthropogenic activities in the vicinity of both locations.

\begin{tabular}{|c|c|c|c|c|c|c|c|c|c|c|c|c|}
\hline \multicolumn{2}{|c|}{ Location } & $\mathbf{P b}$ & Cd & $\mathrm{Cr}$ & $\mathbf{N i}$ & Co & $\mathrm{Cu}$ & $\mathbf{Z n}$ & Mn & Mg & $\mathbf{F e}$ & Reference \\
\hline \multirow{5}{*}{ Yemen } & Al-Salif & 1.20 & 0.19 & 2.13 & 2.80 & 1.25 & 13.00 & 17.65 & 11.33 & \begin{tabular}{|l|}
1188.10 \\
\end{tabular} & 335.50 & \multirow{5}{*}{$\begin{array}{l}\text { Present } \\
\text { study }\end{array}$} \\
\hline & Al-Urj & 2.10 & 0.44 & 2.35 & 3.60 & 1.40 & 19.03 & 15.73 & 14.25 & 1152.55 & 381.25 & \\
\hline & Al-Hodeidah & 3.18 & 0.43 & 3.60 & 4.00 & 2.45 & 24.45 & 21.38 & 17.70 & 1576.23 & 458.25 & \\
\hline & Yakhtol & 0.18 & 0.22 & 1.53 & 2.05 & 0.57 & 14.98 & 15.40 & 9.40 & 1102.78 & 264.00 & \\
\hline & Ghorairah & 2.35 & 0.38 & 2.72 & 2.72 & 1.68 & 19.40 & 19.65 & 12.43 & 1347.75 & 326.00 & \\
\hline \multirow{3}{*}{$\begin{array}{l}\text { Saudi } \\
\text { Arabia }\end{array}$} & Shuaiba & 0.57 & 0.01 & 4.53 & 6.74 & - & 4.17 & 4.23 & 11.14 & - & 39.54 & \multirow{2}{*}{ [47] } \\
\hline & Yanbu & 0.22 & ND & 2.37 & 21.10 & - & 6.83 & ND & 65.95 & - & 375.39 & \\
\hline & $\begin{array}{l}\text { Tarut Bay and } \\
\text { Gurmah Island }\end{array}$ & 6.90 & - & - & - & - & 4.40 & 11.00 & - & - & - & [97] \\
\hline \multirow{2}{*}{ Iran } & Qeshm Island & 0.84 & - & - & 2.44 & - & 37.73 & 33.83 & - & - & - & [17] \\
\hline & Sirik Azini creek & 8.80 & 0.80 & - & 6.20 & - & 9.45 & 20.69 & - & - & & [30] \\
\hline \multirow{6}{*}{ India } & Veli & 79.00 & 3.00 & - & - & 77.00 & 140.00 & 167.00 & 495.00 & - & 6900.00 & \multirow{3}{*}{ [18] } \\
\hline & Kochi & 42.00 & 2.00 & - & - & 55.00 & 68.00 & 146.00 & 510.00 & - & 5500.00 & \\
\hline & Kannur & 28.00 & $<1$ & - & - & 29.00 & 33.00 & 220.00 & 308.00 & - & 10500.00 & \\
\hline & Pichavaram & 7.00 & ND & 19.00 & 1.00 & 0.04 & 33.00 & 18.00 & 17.00 & 799.00 & 525.00 & \multirow{3}{*}{ [84] } \\
\hline & Cuddalore & 6.00 & 0.10 & 20.00 & 3.00 & 0.60 & 12.00 & 9.00 & 5.00 & 571.00 & 131.00 & \\
\hline & Vellar & 2.00 & ND & 3.00 & 1.00 & 0.30 & 47.00 & 17.00 & 26.00 & 1648.00 & 137.00 & \\
\hline \multirow{2}{*}{ China } & Quanzhou Bay & 1.60 & - & 25.00 & 136.00 & 0.30 & 5.30 & 23.40 & 684.00 & - & 237.00 & [56] \\
\hline & Maowei Gulf & 1.57 & 0.20 & 4.82 & 1.25 & - & 1.83 & 18.58 & - & - & - & [48] \\
\hline Thailand & Pattani Bay & 30.30 & 0.40 & 0.40 & 38.30 & - & 10.80 & 11.10 & 224.00 & - & - & [19] \\
\hline Panama & Punta Mala Bay & 6.20 & - & - & - & - & 3.70 & 35.80 & - & - & - & [98] \\
\hline \multirow{4}{*}{ Australia } & & 3.50 & - & - & - & - & 24.80 & 22.10 & - & - & - & \multirow{4}{*}{ [71] } \\
\hline & Port Jackson & 3.90 & - & - & - & - & 10.70 & 35.50 & - & - & - & \\
\hline & Hawksbury & 1.70 & - & - & - & - & 3.20 & 14.30 & - & - & - & \\
\hline & Port Hacking & 0.10 & - & 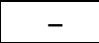 & - & - & 3.20 & 34.00 & - & 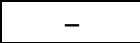 & - & \\
\hline France & New Caledonia & - & 0.16 & - & 0.61 & - & 0.28 & 0.31 & 0.83 & - & 5.59 & [2] \\
\hline \multicolumn{2}{|c|}{$\begin{array}{l}\text { The permissible limit of } \\
\text { heavy metal in plant }\end{array}$} & 2.00 & 0.02 & 1.30 & 10.00 & - & 10.00 & 50.00 & - & 200.00 & - & {$[31]$} \\
\hline
\end{tabular}

Table 2: Comparison between the present results of heavy metals concentrations $(\mu \mathrm{g} / \mathrm{g})$ in mangrove leaves of the study area with earlier reported in the other areas from the world.

$\mathrm{ND}=$ Not detected. 


\section{Journal of Ecology \& Natural Resources}

\section{Conclusion}

The distribution of heavy metals in mangrove leaves during this study may be arranged in the decreasing order as follows: $\mathrm{Mg}>\mathrm{Fe}>\mathrm{Cu}>\mathrm{Zn}>\mathrm{Mn}>\mathrm{Ni}>\mathrm{Cr}>\mathrm{Co}>\mathrm{Pb}>$ $\mathrm{Cd}$. The levels of heavy metal, which accumulate in mangrove leaves of the study area, differ seasonally and spatially. The higher value of these metals in mangrove leaves were at Al-Hodeidah may be due to increasing anthropogenic activities in the vicinity of this site, whereas at Ghorairah may be attributed to the potential contaminants that carried by water currents coming from the Gulf of Aden, through Bab-el-Mandeb Strait. Al-Salif and Yakhtol showed no polluted by heavy metals, this might be due to limited influence of anthropogenic activities at these two sites. Elevated metal concentrations during spring and summer might be associated with increasing biological activities in mangrove ecosystems, terrestrial run off and rainfall during these seasons. The levels of studied metals in mangrove leaves were comparable with corresponding in other less polluted area of the world. Heavy metals concentrations in mangrove leaves were lower than the permissible limits as recommended by WHO, except $\mathrm{Mg}$, $\mathrm{Cu}, \mathrm{Cr}, \mathrm{Pb}$, and $\mathrm{Cd}$. This study indicated that nonessential metals entering in mangrove ecosystems could be accumulated in mangrove leaves and then removed from tree with falling leaves. High levels of $\mathrm{Mg}, \mathrm{Fe}, \mathrm{Mn}, \mathrm{Zn}$ and $\mathrm{Cu}$ in mangrove leaves may be that these metals are micronutrients essential metals for mangrove growth and metabolism and thus absorbed and used by mangrove plant.

It is recommended that, continuous monitoring of levels of heavy metals in mangrove habitats is necessary to avoid being overcome permissible limit (especially at Al-Hodeidah and Ghorairah). Also establishing sustainable programs for regular coastal surveillance to detect polluted mangrove habitats.

\section{Acknowledgements}

The authors are highly thankful to Department of Earth and Environmental Science, Sana'a University, and Geological Survey Minerals Resources Board, Ministry of oil and Minerals, Yemen for their support of the project.

\section{References}

1. Donato DC, Kauffman JB, Murdiyarso D, Kurnianto S, Stidham M, et al. (2011) Mangrove among the most carbon-rich forests in the tropics. Nat Geosci 4(5): 293-297.
2. Deborde J, Marchand C, Molnar N, Della Patrona L, Meziane T (2015) Concentrations and fractionation of $\mathrm{C}, \mathrm{N}, \mathrm{P}, \mathrm{Fe}$, and $\mathrm{S}$ in mangrove sediments along an intertidal gradient (Semi-Arid Climate, New Caledonia). J Mar Sci Eng 3(1): 52-72.

3. Zhang R, Yan C, Liu J (2013) Effect of mangroves on the horizontal and vertical distributions of rare earth elements in sediments of the Zhangjiang Estuary in Fujian Province, SE China. J Coast Res 29(6): 13411350.

4. Xin K, Huang X, Hu J, Li C, Yang X, et al. (2014) Land use Change Impacts on Heavy Metal Sedimentation in Mangrove Wetlands-A Case Study in Dongzhai Harbor of Hainan, China. Wetlands 34(1): 1-8.

5. Sperotto R, Ricachenevsky F, Williams L, Vasconcelos M, Menguer P (2014) From soil to seed: micronutrient movement into and within the plant. Front. Plant Sci 5: 438-441.

6. Ramos GM, Geraldo LP (2007) Assessment of Avicennia schaueriana, Laguncularia recemosa and Rhizophora mangle Plant Species as Bioindicator of Heavy Metal Pollution in Mangrove Environments. Engenharia Sanitaria e Ambiental 12(4): 440-445.

7. Bayen S (2012) Occurrence, bioavailability and toxic effects of trace metals and organic contaminants in mangrove ecosystems: a review. Environ Int 48: 84101.

8. Anouti FA (2014) Bioaccumulation of Heavy Metals within Mangrove Ecosystems. J Biodivers Endanger Species 2(2): 1-2.

9. Chakraborty P, Ramteke D, Chakraborty S (2015) Geochemical partitioning of $\mathrm{Cu}$ and $\mathrm{Ni}$ in mangrove sediments: relationships with their bioavailability. Mar Pollut Bull 93(1-2): 194-201.

10. Lacerda L, Martinelli L, Rezende C, Mozetto A, Ovalle A, et al. (1988) The fate of heavy metals in suspended matter in a mangrove creek during a tidal cycle. Sci Total Environ 75(2-3): 169-180.

11. Mackey AP, Hodgkinson MC (1995) Concentration and spatial distribution of trace metals in mangrove sediments from the Brisbane River, Australia. Environ Pollut 90(2): 181-186.

12. Tam N, Wong Y (2000) Spatial variation of heavy metals in surface sediments of Hong Kong mangrove swamps. Environ Pollut 110(2): 195-205. 
13. Pumijumnong N, Danpradit S (2016) Heavy Metal Accumulation in sediments and Mangrove Forest Stems from Surat Thani Provice, Thailand. Malaysian Forester 79(1-2): 212-228.

14. MacFarlane GR, Pulkownik A, Burchett MD (2003) Accumulation and distribution of heavy metals in the grey mangrove, Avicennia marina (Forsk.) Vierh: biological indication potential. Environ Pollut 123(1): 139-151.

15. Ramanathan A, Subramanian V, Ramesh R, Chidambaram S, James A (1999) Environmental geochemistry of the Pichavaram mangrove ecosystem (tropical), SE coast of India. Environ Geol 37(3): 223233.

16. Tam N, Yao M (1998) Normalization and heavy metal contamination in mangrove sediments. Sci. Total Environ 216(1-2): 33-39.

17. Einollahipeer F, Khammar S, Sabaghzadeh A (2013) A Study on Heavy Metal Concentration in Sediment and Mangrove (Avicenia marina) Tissues in Qeshm Island, Persian Gulf. J Novel Appl Sci 2(10): 498-504.

18. Badarudeen A, Sajan K, Srinivas R, Maya K, Padmalal D (2014) Environmental significance of heavy metals in leaves and stems of Karala mangroves, SW coast of India. Indian J Mar Sci 43(6): 1027-1035.

19. Kaewtubtim P, Meeinkuirt W, Seepom S, Pichtel J (2016) Heavy metal phytoremediation potential of plant species in a mangrove ecosystem in Pattani Bay, Thailand. Appl Ecol Environ Res 14(1): 367-382.

20. APHA (2005) Standard Methods for the Examination of Water and Wastewater. 21 ${ }^{\text {st }}$ (Edn.), CRC Press, USA.

21. Perkin-Elmer Corporation (1996) Analytical Methods for Atomic Absorption Spectroscopy. A Manual Published by Perkin-Elmer Corporation, US.

22. Nazir R, Khan M, Masab M, Ur Rehman H, Ur Rauf N, et al. (2015) Accumulation of Heavy Metals (Ni, Cu, $\mathrm{Cd}, \mathrm{Cr}, \mathrm{Pb}, \mathrm{Zn}, \mathrm{Fe}$ ) in the soil, water and plants and analysis of physico-chemical parameters of soil and water Collected from Tanda Dam kohat. J Pharmaceut Sci Res 7(3): 89-97.

23. Qiu YW, Yu K, Zhang G, Wang WX (2011) Accumulation and partitioning of seven trace metals in mangroves and sediment cores from three estuarine wetlands of Hainan Island, China. J Hazard Mater 190(1-3): 631-638.
24. Tsade HK (2016) Atomic Absorption Spectroscopic Determination of Heavy Metal Concentrations in Kulufo River, Arbaminch, Gamo Gofa, Ethiopia. J Environ Analyt Chem 3: 177-180.

25. Panda SS, Chaturvedi N, Dhal N, Rout N (2013) An assessment of heavy metal accumulation in mangrove species of Bhitarkanika, Odisha, India. Res Plant Biol 3(6): 1-5.

26. Duan JC, Tan JH, Hao J, Wang S, Hao J, et al. (2012) Size distributions and sources of elements in particulate matter at curbside, urban and rural sites in Beijing. J Environ Sci (China) 24(1): 87-94.

27. Awofolu OR, Mbolekwa Z, Mtshemla V, Fatoki OS (2005) Levels of Trace Metals in Water and Sediment from Tyume River and its effects on an irrigated farmland. Water SA 31(1): 87-94.

28. Hussain A, Abbas N, Arshad F, Akram M, Khan Z, et al. (2013) Effects of diverse doses of $\mathrm{Pb}$ on different growth attributes of Zea-Mays L. Agric Sci 4(5): 262265.

29. Kazemipour M, Ansari M, Tajrobehkar S, Majdzadeh M, Kermani H (2008) Removal of Pb(II), cadmium, zinc, and copper from industrial wastewater by carbon developed from walnut, hazelnut, almond, pistachio shell, and apricot stone. J Hazard Mater 150(2): 322-327.

30. Parvaresh $H$, Abedi $Z$, Farshchi $P$, Karami M, Khorasani N, et al. (2011) Bioavailability and concentration of heavy metals in the sediments and leaves of grey mangrove, Avicennia marina (Forsk.) Vierh, in SirikAzini Creek, Iran. Biol Trace Elements Res 143(2): 1121-1130.

31. WHO (1996) Permissible limits of heavy metals in soil and plants. WHO, Geneva, Switzerland.

32. Zheng WJ, Cheng XY, Lin P (1997) Accumulation and biological cycling of heavy metal elements in Rhizophora stylosa mangroves in Yingluo Bay, China. Mar Ecol Prog Ser 159: 293-301.

33. Machado W, Moscatelli M, Rezende L, Lacerda L (2002) Mercury, zinc and copper accumulation in mangrove sediments surrounding a large landfill in southeast Brazil. Environ Pollut 120(2): 455-461.

34. Akan JC, Abdulrahman F, Ogugbuaja V, Ayodele J (2009) Heavy metals and anion levels in some samples of vegetables grown within the vicinity of 
Challawa Industrial Area, Kano state, Nigeria. Am J Appl Sci 6(3): 534-542.

35. Sarkar S, Favas P, Rakshit D, Satpathy K (2014) Geochemical Speciation and Risk Assessment of Heavy Metals in Soils and Sediments. In: HernandezSoriano MC (ed.), Environmental Risk Assessment of Soil Contamination. Intech 723-757.

36. Benavides MP, Gallego SM, Tomaro ML (2005) Cadmium toxicity in plants. Brazilian J Plant Physiol 17(1): 21-34.

37. Feng $\mathrm{H}$, Jiang $\mathrm{H}$, Gao $\mathrm{W}$, Weinstein $\mathrm{M}$, Zhang $\mathrm{Q}$, et al. (2011) Metal contamination in sediments of the western Bohai Bay and adjacent estuaries, China. J Environ Manag 92(4): 1185-1197.

38. Huang HJ, Yuan X, Zeng G, Zhu H, Li H, et al. (2011) Quantitative evaluation of heavy metals pollution hazards in liquefaction residues of sewage sludge. Bioresource Technol 102(22): 10346-10351.

39. Álvarez-Fernández A, Díaz-Benito P, Abadía A, López Millán A, Abadía J (2014) Metal species involved in long distance metal transport in plants. Front Plant Sci 5(105): 1-20.

40. Naser HM, Sultana S, Mahmud NU, Gomes R, Noor S (2011) Heavy Metal Levels in Vegetables with Growth Stage and Plant Species Variations. Bangladesh J Agril Res 36(4): 563-574.

41. Allen SE (1989) Chemical Analysis of Ecological Materials. $2^{\text {nd }}($ Edn.), Blackwell Scient Publ, USA, pp: 368.

42. Wuana RA, Okieimen FE (2011) Heavy Metals in Contaminated Soils: A Review of Sources, Chemistry, Risks and Best Available Strategies for Remediation. Communications Soil Sci Plant Analy 42: 111-122.

43. Wu Q, Tam N, Leung J, Zhou X, Fu J, et al. (2014) Ecological risk and pollution history of heavy metals in Nansha mangrove, South China. Ecotoxicol Environ Saf 104: 143-151.

44. Rajappa B, Manjappa S, Puttaiah E (2010) Monitoring of Heavy metal in groundwater of Hakinaka TaluK, India. Contemporary Eng Sci 3(4): 183-190.

45. Jain M, Pal M, Gupta P, Gadre R (2007) Effect of cadmium on chlorophyll biosynthesis and enzymes of nitrogen assimilation in greening maize leaf segments: role of 2-oxoglutarate. Indian J Experiment Biol 45(4): 385-389.

46. Shanker AK, Cervantes C, Loza-Tavera H, Avudainyagam S (2005) Chromium toxicity in plants. Environ Int 31(5): 739-753.

47. Abohassan RA (2013) Heavy Metal Pollution in Avicennia marina Mangrove Systems on the Red Sea Coast of Saudi Arabia. JKAU: Meteorol. Environ Arid Land Agric Sci 24(1): 35-53.

48. Wu Z, Geng J, Huang L (2015) Heavy Metal Contamination in Sediments and Mangroves from Maowei Gulf, South China. Fresen Environ Bull 24(3): 1091-1097.

49. Rahman M, Fikria A, Kamaruzzaman B, Nik W (2012) Distribution of trace metals in pore water along Terengganu beach. Australian J Basic Appl Sci 6(7): 213-217.

50. Liu J, Wu H, Feng J, Li Z, Lin G (2014) Heavy metal contamination and ecological risk assessments in the sediments and zoobenthos of selected mangrove ecosystems, South China. Catena 119: 136-142.

51. Asati A, Pichhode M, Nikhil K (2016) Effect of Heavy Metals on Plants: An Overview. Int J Appl Innov Eng Manag 5(3): 56-61.

52. Sharma A, Dhiman A (2013) Nickel and Cadmium Toxicity in Plants. J Pharmaceut Sci Innov 2(2): 20-24.

53. Du P, Xie YF, Wang SJ, Zhao H, Zhang Z, et al. (2015) Potential Sources of and Ecological Risks from Heavy Metals in Agricultural Soils, Daye City, China. Environ Sci Pollut Res 22(5): 3498-3507.

54. Bhagure GR, Mirgane S (2010) Heavy Metals Contaminations in groundwater and soils of Thane Region of Maharashtra, India. Environ Monit Assess 173(1-4): 643-52.

55. Hardy DH, Myers J, Stokes C (2008) Heavy Metals in North Carolina Soils: Occurrence and Significance. NC Depart Agric Consum Ser 1-2.

56. Brooks RR (1977) Copper and cobalt uptake be Haumaniastrum species. Plant Soil 48(2): 541-544.

57. Yu R, Hu G, Zhang W, Liu B (2015) Accumulation and Transfer of Heavy Metals in the Mangroves from Quanzhou Bay Wetland, SE Coast of China. J Residuals Sci Technol 12(1): 79-83. 


\section{Journal of Ecology \& Natural Resources}

58. Palit S, Sharma A, Talukdar G (1994) Effects of cobalt on plants. Botanical Review 60(2): 149-181.

59. Bowen H (1966) Trace Elements in Biochemistry. Acad Press, USA, pp: 244.

60. Smith KA, Paterson JE (1990) Manganese and cobalt. In: Alloway B J (Ed), $2^{\text {nd }}$ (Edn.), Heavy metals Soils. Blackie Acad Prof, London, pp: 224-244.

61. Finkelman RB (2005) Sources and health effects of metals and trace elements in our environment: An Overview. In: Moor TA, Black A, Centeno J, Harding J, Trumm, DA (Eds.), $2^{\text {nd }}$ (Edn.), Metal Contaminants in New Zealand. Resolution Press, Christchurch, New Zealand, pp: 25-46.

62. Kim GY, Lee JY, Lee JO, Ryu CH, Choi BT, et al. (2006) Partial characterization and immunostimulatory effect of a novel polysaccharide protein complex extracted from Phellinus linteus. Biosci Biotechnol Biochem 70(5): 1218-1226.

63. Sheldon A, Menzies N (2005) The effect of copper toxicity on the growth and root morphology of Rhodes grass (Chloris gayana Knuth.) in resin buffered solution culture. Plant and Soil 278(1-2): 341-349.

64. Reichman SM (2002) The responses of plants to metal toxicity: a review focusing on copper, manganese and zinc, Australian Miner, Energy Environ. Found: 54.

65. Pahlsson AM (1989) Toxicity of heavy metals ( $\mathrm{Zn}, \mathrm{Cu}$, $\mathrm{Cd}, \mathrm{Pb}$ ) to vascular plants. Water Air Soil Pollut 47(3): 287-319.

66. Baker DE, Senef JP (1995) Copper. In: Alloway B (Ed), Heavy metals Soils. $2^{\text {nd }}($ Edn.), Blackie Acad Prof, New York, pp: 179-205.

67. Marchand $C$, Lallier-Vergès E, Baltzer F, Albéric $P$, Cossa D, et al. (2006) Heavy metals distribution in mangrove sediments along the mobile coastline of French Guiana. Mar Chem 98(1): 1-17.

68. Churong W, Xin R, Wenxiu L, Zhifei H, Chao K, et al. (2013) Adsorption of Zinc and Copper Heavy Metal Ions from Smelting Waste Water using Modified Lava Particles. J Environ Stud 22(6): 1863-1869.

69. Salminen R, Demetriades A, Reeder S (2005) Geochemical Atlas of Europe, Part 1- Background Information, Methodology and Maps, Geological Survey of Finland. Otamedia Oy, Espoo, pp: 525.
70. Moolenaar SW (1998) Sustainable management of heavy metals in agro-ecosystems. Ph.D. Thesis, Wageningen Univ, Netherlands, pp: 191.

71. MacFarlane GR (2002) Leaf biochemical parameters in Avciennia marina (Forsk.) Vierh as potential biomarkers of heavy metals stress in Estuarine ecosystems. Mar Pollut Bull 44(3): 244-256.

72. Sharma Y, Srivastava V, Singh V, Kaul S, Weng C (2004) Nano-adsorbents for the Removal of Metallic Pollutants from Water and Wastewater. Environ Technol 30(6): 583-609.

73. Bradi BH (2005) Heavy Metals in the Environment: Origin, Interaction and Remediation Acad Press, USA, Interface Sci Technol 6: 282.

74. Zhang R, Yan C, Liu J (2013) Effect of mangroves on the horizontal and vertical distributions of rare earth elements in sediments of the Zhangjiang Estuary in Fujian Province, SE China. J Coast Res 29(6): 13411350.

75. Lei Y, Korpelainen H, Li C (2007) Physiological and biochemical responses to high Mn concentrations in two contrasting Populus cathayana populations. Chemosphere 68(4): 686-694.

76. Millaleo R, Reyes-Diaz M, Ivanov A, Mora M, Alberdi M (2010) Manganese as essential and toxic element for plants: Transport, accumulation and Resistance Mechanisms. J Soil Sci Plant Nutr 10(4): 470-481.

77. Arora M, Kiran B, Rani S, Rani A, Kaur B, et al. (2008) Heavy metal accumulation in vegetables irrigated with water from different sources. Food Chem 111(4): 811-815.

78. Ducic T, Polle A (2005) Transport and detoxification of manganese and copper in plants. Brazilian J Plant Physiol 17(1): 103-112.

79. Clarkson D (1988) The uptake and translocation of manganese by plant roots. In: Graham R, Hannam R, Uren $N$ (Eds.), Manganese in Soil and Plants, $2^{\text {nd }}$ (Edn.), Kluwer Acad Publ, Netherlands, pp: 101-111.

80. Kamaruzzaman B, Nurulnadia M, Azhar N, Shahbudin $\mathrm{S}$, Joseph B (2011) Vertical variation of $\mathrm{Pb}, \mathrm{Cu}$ and $\mathrm{Mn}$ in core sediments collected from Tanjung Lumpur mangrove forest, Pahang, Malaysia. Sains Malaysiana 40(8): 827-830. 
81. Hronec O, Vilcek J, Toma J, Adamiin P, Huttmanova E (2010) Environmental components quality problem areas in Slovakia, Mendelova Univ, Brno, pp: 225.

82. Mahajan S, Billore D (2014) Assessment of PhysicoChemical characteristics of the Soil of Nagchoon Pond Khandwa, MP, India. Res J Chem Sci 4(1): 26-30.

83. Marschner H (1995) Mineral Nutrition of Higher Plants. 2nd (Edn.), Acad Press, London, pp: 889.

84. Kathiresan K, Saravanakumar K, Mullai M (2014) Bioaccumulation of trace elements by Avicennia marina. J Coast Life Med 2(11): 888-894.

85. Cox RH, Shealy CN, Cady RK, Veehoff D, Burnetti M, et al. (1996) Significant magnesium deficiency in depression. J Neurol Orthop Med Surg 17(1): 7-9.

86. Vincoli JW (1997) Risk Management for Hazardous Chemicals, CRC Press Inc, New York, 2: 3136.

87. Shah A, Niaz A, Ullah N, Rehman A, Akhlaq M, et al. (2013) Comparative study of heavy metals in soil and selected medicinal plants. J Chem 1-5.

88. Arya SK, Roy BK (2011) Manganese induced changes in growth, chlorophyll content and antioxidants activity in seedlings of broad bean (Vicia faba L.). J Environ Biol 32(6): 707-711.

89. Becker M, Asch F (2005) Iron toxicity in rice conditions and management concepts. J Plant Nutrition Soil Sci 168(4): 558-573.

90. Samaranayake P, Peiris B, Dssanayake S (2012) Effect of excessive ferrous $\left(\mathrm{Fe}^{2+}\right)$ on growth and iron content in rice (Oryza sativa). Int J Agri Biol 14(2): 296-298.
91. Zou J, Sun J, Dai W, Yao Z, Yang T, et al. (2013) Evaluation and analysis of heavy metals in cultivated soils in the suburbs of Beijing. J Beijing Forestry Univ 35: 132-138.

92. Reimann C, Siewers U, Tarvainen T, Bityukova L, Eriksson J (2003) Agricultural Soils in Northern Europe: A Geochemical Atlas. In: Geol J, Sonderhefte, Reihe DE (Eds.), Stuttgart, Germany, pp: 279.

93. FAO/WHO (1984) List of maximum levels recommended for contaminants by the Joint FAO/WHO Codex Alimentarius Commission ( $3^{\text {rd }}$ Series), CAC/FAL, Rome, 3: 1-8.

94. Rudnick R, Gao S (2004) Composition of the Continental Crust. In: Holland H, Turekian K (Eds.), Treatise on Geochemistry. Elsevier, 3: 1-64.

95. Kabata-Pendias A (2001) Trace Elements in Soil and Plants. $2^{\text {nd }}($ Edn.), CRC Press Inc., Florida, pp: 489.

96. Degryse F, Smolders E, Merckx R (2006) Labile Cd complexes increase $\mathrm{Cd}$ availability to plants. Environ Sci Technol 40(3): 830-836.

97. Sadiq M, Zaidi T (1994) Sediment composition and metal concentrations in mangrove leaves from the Saudi coast of the Arabian Gulf. Sci Total Environ 155(1): 1-8.

98. Defew LH, Mair JM, Guzman HM (2005) An Assessment of Metal Contamination in Mangrove Sediments and Leaves from Punta Mala Bay, Pacific Panama. Mar Pollut Bull 50(5): 547-552. 